\title{
INFLUENCE OF OFF-SEASON LAND MANAGEMENT ON MAXIMIZING YIELD AND QUALITY OF CURCUMA LONGA L. CULTIVARS
}

\section{A. ANBURANI*}

Department of Horticulture, Faculty of Agriculture, Annamalai University, Annamalai Nagar 608002, Tamil Nadu, India

\begin{abstract}
The present investigation was carried out to study the effect of off season soil management practices on yield and quality of turmeric (Curcuma longa L.) cultivars. The experiment was laid out in a Factorial Randomized Block Design with ten treatments in three replications consisted of five off-season land management treatments viz., fallow $\left(\mathrm{S}_{1}\right)$, summer ploughing 2 times $\left(\mathrm{S}_{2}\right)$, summer ploughing 1 time $\left(\mathrm{S}_{3}\right)$, solarization with transparent polyethylene film of $0.05 \mathrm{~mm}$ thick for $40 \mathrm{~d}\left(\mathrm{~S}_{4}\right)$ and black polyethylene film for $40 \mathrm{~d}\left(\mathrm{~S}_{5}\right)$. It was tested with two popular cultivars viz., Curcuma longa-1 CL-1 ( $\left.\mathrm{V}_{1}\right)$ and Curcuma longa-2 CL-2 $\left(\mathrm{V}_{2}\right)$, collected from Erode and Chidambaram. Various yield components were recorded at the time of harvest and were analysed. The yield attributing characters viz., number, length, girth and weight of mother, primary and secondary rhizomes were recorded. The treatment where solarization with transparent polyethylene film of $0.05 \mathrm{~mm}$ thick was tested recorded the highest yield and yield attributing characters when compared to other treatments. The same treatment also exhibited the highest fresh rhizome yield per plant, curing percentage and cured rhizome yield. The quality parameters like curcumin, oleoresin and essential oil content were also showed superior performance in the treatment where solarization with transparent polyethylene film of $0.05 \mathrm{~mm}$ thick was applied.
\end{abstract}

Keywords: Off season land management, Turmeric, Coastal region

\section{INTRODUCTION}

Turmeric (Curcuma longa L.) an ancient and sacred spice of India is a major rhizomatous crop produced and exported from India. It is also called as "Indian Saffron" because of its brilliant yellow colour. The value of turmeric as food and medicine has been recognized since early ages. Apart from culinary purposes turmeric is traditionally used for medicinal, religious, cosmetics and in dye preparations [1]. The most striking feature of turmeric is, its dark yellow pigment curcumin, which is used as a natural colorant in baked foods, pharmaceuticals and other preparations. In the international market the value of turmeric is determined by its curcumin content [2]. Not only weeds, pests and diseases also known to have a great impact on yield of turmeric. In Tamil Nadu the major pest in turmeric is shoot borer caused by Dichocroces punctiferalis and the major disease is rhizome rot caused by Pythium graminicolum. Crop loss due to weed is more than $40 \%$ [3] and pest and disease is $50-80 \%[4]$.

Off-season land management through soil solarization is a technique, which was first developed and practiced in Israel for the management of plant pathogens [5]. Subsequent research proves that it is a very effective mechanism in controlling weed population. Off-season land management-A technique of soil preparation before planting has claimed to be an integrated method of improving soil and plant health. It involves soil solarization, a non-pesticidal method of controlling soilborne pests by placing plastic sheets on moist soil during periods of high ambient temperature. Hence, the present investigation was carried out to study the effect of off season soil management practices on yield and quality of turmeric cultivars.

\section{MATERIALS AND METHODS}

\section{Experimental site}

The experiment was conducted in a farmer's field at Vallampadugai village located $8 \mathrm{~km}$ away from Chidambaram in the Cuddalore district of Tamil Nadu, India.

\section{Crop and variety}

The two turmeric cultivars viz., Curcuma longa-1 and Curcuma longa-2 popularly grown in this region were utilized for the present study. The key characteristics of the cultivars are presented below.

\section{Experimental design}

The treatments were laid in Factorial Randomized Block Design with three replications.

\section{Received 21 March 2018; Accepted 02 May 2018}

*Corresponding Author

\section{A. Anburani}

Department of Horticulture, Faculty of Agriculture, Annamalai University, Annamalai Nagar 60 8002, Tamil Nadu, India Email: anbumohankarthi2007@rediffmail.com

(T) This article is open access and licensed under the terms of the Creative Commons Attribution License (http://creativecommons.org/licenses/by/4.o/) which permits unrestricted, use, distribution and reproduction in any medium, or format for any purpose, even commercially provided the work is properly cited. Attribution - You must give appropriate credit, provide a link to the license, and indicate if changes were made. 
Sources of inputs

\begin{tabular}{lll}
\hline S. No. & Particulars & Sources \\
\hline I. & Seed materials (Turmeric) & \\
& a. Curcuma longa-1 & Collected from Erode. \\
& b. Curcuma longa-2 & Collected from Chidambaram. \\
\hline
\end{tabular}

\section{Treatment details}

\begin{tabular}{lll}
\hline S. No. & Treatment details & Abbreviations used \\
\hline I & Off-season land management & S \\
1. & Fallow & $\mathrm{S}_{1}$ \\
2. & Summer ploughing 2 times (15 d interval) & $\mathrm{S}_{2}$ \\
3. & Summer ploughing 1 time & $\mathrm{S}_{3}$ \\
. & Soil solarization through transparent polyethylene film (o.05 mm thickness) for 40 d & $\mathrm{S}_{4}$ \\
5. & Soil solarization through black polyethylene film for 40 d & $\mathrm{S}_{5}$ \\
II & Cultivars & $\mathbf{V}$ \\
1. & Curcuma longa-1 (CL-1) & $\mathrm{V}_{1}$ \\
2. & Curcuma longa-2 (CL-2) & $\mathrm{V}_{2}$ \\
\hline
\end{tabular}

\section{Treatment combinations}

$\mathrm{T}_{1-} \mathrm{S}_{1} \mathrm{~V}_{1}$

$\mathrm{T}_{2-} \mathrm{S}_{1} \mathrm{~V}_{2}$

$\mathrm{T}_{3}-\mathrm{S}_{2} \mathrm{~V}_{1}$

$\mathrm{T}_{4}-\mathrm{S}_{2} \mathrm{~V}_{2}$

$\mathrm{T}_{5}-\mathrm{S}_{3} \mathrm{~V}_{1}$

$\mathrm{T}_{6}-\mathrm{S}_{3} \mathrm{~V}_{2}$

$\mathrm{T}_{7-} \mathrm{S}_{4} \mathrm{~V}_{1}$

$\mathrm{T}_{8}-\mathrm{S}_{4} \mathrm{~V}_{2}$

$\mathrm{T}_{9}-\mathrm{S}_{5} \mathrm{~V}_{1}$

$\mathbf{T}_{10}-\mathbf{S}_{5} \mathbf{V}_{2}$

\section{Off-season land management}

The experimental field was divided into five equal strips of which, one was for the fallow and the others were subjected to off-season land management treatments in four different methods. Immediately after receiving the summer showers, the solarization works were started in strips (strips allotted for summer ploughing 1 and 2 times) by ploughing one time in one strip and in the another strip for two times at $15 \mathrm{~d}$ interval so as to bring the soil to a fine tilth and more aerated. Similarly, ploughing was carried out in the remaining two strips also and irrigated to the field capacity. Then the solarization treatment was done for $40 \mathrm{~d}$ in May-June by covering with transparent polyethylene film of $0.05 \mathrm{~mm}$ thick in one strip and with black polyethylene film in another strip. The polyethylene films should be tarped over the levelled soil and the sides were buried into the soil to maintain air tight condition. However, the fallow strip was kept free without imposing any treatment. Then the required quantity of organic manure (25 tha-1 of FYM) and inorganic nutrients (125:60:60 $\mathrm{kg} \mathrm{NPK} \mathrm{ha}^{-1}$ ) were applied as per the standard recommendation. Farmyard manure was incorporated as basal dose. The inorganic nutrients viz., nitrogen in the form of urea was applied in five split doses at 30, 60, 90 and $120 \mathrm{~d}$ after planting. The entire phosphorus was applied in the form of single superphosphate and potassium was applied as muriate of potash in three split doses (basal dose, 60 and 120 DAP). The required intercultural operations and plant protection measures were carried out as per the recommendation. Six plants were randomly selected and tagged for recording observation. Statistical analysis was done as per the standard procedure [6].

Table 1: Influence of off-season land management on yield characters in turmeric cultivation

\begin{tabular}{|c|c|c|c|c|c|c|c|c|c|c|c|c|c|c|}
\hline \multicolumn{4}{|c|}{ Number of rhizomes } & \multicolumn{2}{|c|}{ Length (cm) } & \multicolumn{3}{|c|}{ Girth } & \multicolumn{4}{|c|}{ Weight (g/plant) } & \multirow{2}{*}{$\begin{array}{l}\text { Yield } \\
\text { (g/plant) }\end{array}$} & \multirow{2}{*}{$\begin{array}{l}\text { Cured } \\
\text { rhizome } \\
\text { yield } \\
\text { (kg ha-1) }\end{array}$} \\
\hline & Mother & Primary & Secondary & Mother & Primary & Secondary & Mother & Primary & Secondary & Mother & Primary & Secondary & & \\
\hline $\mathrm{V} 1 \mathrm{~S} 1$ & 1.08 & 4.61 & 9.04 & 2.32 & 6.24 & 1.70 & 4.86 & $4 \cdot 32$ & 2.87 & $17 \cdot 74$ & 79.46 & 47.29 & 144.49 & 929.17 \\
\hline $\mathrm{V} 1 \mathrm{~S} 2$ & 1.78 & 6.00 & 10.49 & 3.44 & 7.28 & 2.22 & 6.40 & 5.02 & 3.59 & 28.43 & 318.27 & 49.43 & 396.13 & 2013.56 \\
\hline $\mathrm{V} 1 \mathrm{~S}_{3}$ & 1.72 & 5.86 & 10.36 & $3 \cdot 34$ & 7.18 & 2.18 & 5.63 & 4.81 & 3.53 & 23.25 & 211.92 & 48.43 & 283.60 & 1782.91 \\
\hline $\mathrm{V}_{1} \mathrm{~S}_{4}$ & 2.69 & $7 \cdot 79$ & 12.37 & 4.90 & 8.64 & 2.87 & 6.83 & $5 \cdot 57$ & 4.53 & 32.89 & 405.94 & 50.29 & 489.12 & 4331.30 \\
\hline $\mathrm{V}_{1} \mathrm{~S}_{5}$ & 2.41 & 7.24 & 11.76 & 4.45 & 8.22 & 2.67 & 6.40 & $5 \cdot 35$ & 4.24 & 29.16 & 360.05 & 49.84 & 439.05 & 3680.40 \\
\hline $\mathrm{V}_{2} \mathrm{~S}_{1}$ & 1.01 & 4.48 & 8.91 & 2.21 & 6.14 & 1.67 & 4.77 & 4.28 & 2.81 & 17.33 & $63.5^{8}$ & 47.10 & 128.01 & 799.54 \\
\hline $\mathrm{V} 2 \mathrm{~S} 2$ & 1.43 & 5.29 & 9.77 & 2.87 & 6.78 & 1.97 & 5.29 & 4.60 & 3.22 & 22.51 & 166.47 & 48.29 & 237.27 & 1486.70 \\
\hline $\mathrm{V}_{2} \mathrm{~S}_{3}$ & 1.38 & 5.17 & 9.64 & 2.75 & 6.67 & 1.92 & 5.20 & 4.54 & 3.16 & 20.29 & 120.49 & 47.86 & 188.64 & 1294.16 \\
\hline $\mathrm{V}_{2} \mathrm{~S}_{4}$ & 2.34 & 7.10 & 11.65 & 4.34 & 8.12 & 2.62 & 6.06 & $5 \cdot 30$ & 4.17 & 27.88 & 279.34 & 49.28 & 356.50 & 3467.86 \\
\hline $\mathrm{V}_{2} \mathrm{~S}_{5}$ & 2.07 & 6.57 & 11.0 & 3.90 & 7.64 & 2.41 & $5 \cdot 72$ & 5.06 & 3.86 & 25.47 & 242.72 & 48.81 & 317.01 & 2020.11 \\
\hline SED & 0.08 & 0.16 & 0.18 & 0.13 & 0.13 & 0.06 & 0.10 & 0.07 & 0.08 & 0.70 & 14.90 & 0.15 & 11.08 & 139.18 \\
\hline $\begin{array}{l}\text { CD } \\
(p=0.05)^{*}\end{array}$ & 0.18 & 0.34 & 0.37 & 0.28 & 0.27 & 0.13 & 0.22 & 0.14 & 0.18 & 1.47 & 31.30 & 0.32 & 23.27 & 292.42 \\
\hline
\end{tabular}


Table 2: Influence of off-season land management on quality characters in turmeric cultivars

\begin{tabular}{llll}
\hline & Curcumin content (\%) & Oleoresin content (\%) & Essential oil content (\%) \\
\hline V1S1 & 2.82 & 7.66 & 1.94 \\
V1S2 & 3.23 & 8.06 & 2.32 \\
V1S3 & 3.08 & 8.01 & 2.12 \\
V1S4 & 3.51 & 8.52 & 2.43 \\
V1S5 & 3.38 & 8.37 & 2.34 \\
V2S1 & 2.78 & 7.62 & 1.90 \\
V2S2 & 2.97 & 7.88 & 2.05 \\
V2S3 & 2.93 & 7.82 & 2.01 \\
V2S4 & 3.35 & 8.20 & 2.24 \\
V2S5 & 3.10 & 8.25 & 2.13 \\
SED & 0.04 & 0.04 & 0.03 \\
CD $(p=0.05)^{*}$ & 0.08 & 0.09 & 0.06 \\
\hline
\end{tabular}

\section{RESULTS}

The yield attributing characters viz., number, length, girth and weight of mother, primary and secondary rhizomes were recorded. The treatment where solarization with transparent polyethylene film of $0.05 \mathrm{~mm}$ thick was tested recorded the highest yield and yield attributing characters when compared to other treatments. The same treatment also exhibited the highest fresh rhizome yield per plant, curing percentage and cured rhizome yield. The quality parameters like curcumin, oleoresin and essential oil content were also showed superior performance in the treatment where solarization with transparent polyethylene film of $0.05 \mathrm{~mm}$ thick was applied.

\section{DISCUSSION}

The observations on rhizome yield per plant (489.12 g), yield per plot $(13.10 \mathrm{~kg})$ and yield per hectare $(24567.77$ $\mathrm{kg}$ ) were recorded the highest due to the effect of transparent polyethylene film of $0.05 \mathrm{~mm}$ thick. This was followed by the treatment where black polyethylene film was applied which recorded rhizome yield of $439.05 \mathrm{~g}$ plant ${ }^{-1}, 11.38 \mathrm{~kg} \mathrm{plot}^{-1}$ and $21335.65 \mathrm{~kg} \mathrm{ha}^{-1}$. The lowest rhizome yield per plant $(128.01 \mathrm{~g})$, yield per plot $(2.76 \mathrm{~kg})$ and yield per hectare $(5175.03 \mathrm{~kg})$ were recorded in fallow plots. Similar results were supported by the findings of [3] in ginger who opined that mulches were useful in altering hydrothermal regime of the soil and provide favorable environment for rhizome development. Earlier report [7] in ginger also showed that application of mulch might have checked the weed growth, reduced the evapotranspiration losses which provide congenial condition for better penetration, proliferation and ramification of roots thereby increased the yield.

Among the two cultivars studied, Curcuma longa-1 showed significant difference in rhizome characters like number, length, girth and fresh weight of mother, primary and secondary rhizomes and rhizome yield when compared to Curcuma longa-2. The variation in rhizome characters is mostly due to the accumulation of more photosynthates and genetic potential of cultivar. Similar variations among the cultivars in turmeric were observed earlier $[8,9]$.

Curing percentage is the proportion of dried product to the fresh rhizomes. In the present investigation the highest curing percentage of 17.63 and cured rhizome yield of $4331.30 \mathrm{~kg} \mathrm{ha}^{-1}$ were recorded in the treatment of transparent polyethylene film of $0.05 \mathrm{~mm}$ thick. It was followed by black polyethylene film, recorded curing percentage of $\mathbf{1 7 . 2 5}$ and cured rhizome yield of $3680.40 \mathrm{~kg} \mathrm{ha}{ }^{-1}$. Whereas the lowest curing percentage of 15.45 and cured rhizome yield of $799.54 \mathrm{~kg} \mathrm{ha}^{-1}$ were recorded in fallow plots. The probable reason for lowest curing percentage and cured rhizome yield under this treatment may be due to high moisture and less lignification of the rhizomes. Similar findings were observed in turmeric [10].

Regarding cultivars the curing percentage and cured rhizome yield was performed better in Curcuma longa-1 when compared to Curcuma longa-2. Similar findings of varied curing percentage and cured rhizome yield in different agro climatic conditions and cultivars were reported earlier [11-13].

In any production system, the primary goal is to achieve maximum yield per unit area without affecting the quality. The rhizome quality in turmeric was mainly judged by curcumin, oleoresin and essential oil content. The highest percentage of curcumin (3.51 per cent) oleoresin (8.52 per cent) and essential oil content (2.43 per cent) were registered under transparent polyethylene film of $0.05 \mathrm{~mm}$ thick. Whereas the black polyethylene film recorded the curcumin content of 3.38 per cent, oleoresin of 8.37 per cent and essential oil content of 2.34 per cent. The least curcumin (2.78 per cent), oleoresin (7.62 per cent) and essential oil content (1.90 per cent) were recorded in fallow plots.

Increase in quality parameters in the solarization treatment might be due to improved disease and weed control, increase in soluble nutrients and relatively greater populations of beneficial soil microorganisms. Similar findings of increase in quality parameters due to solarization was observed earlier [14]. With respect to cultivars performance, the highest curcumin, oleoresin and essential oil content were recorded in the cultivar Curcuma longa-1. The variations for curcumin, oleoresin and essential oil content among the cultivars might be due to genetic factors since the cultivars were grown under similar agro climatic conditions $[15,16]$.

\section{CONCLUSION}

Based on the present investigation, the highest yield and quality characters were recorded the highest in the treatment combination of solarization with transparent polyethylene film of $0.05 \mathrm{~mm}$ thick tested with the cultivar CL-1 $\left(\mathrm{V}_{1}\right)$ collected from Erode.

\section{REFERENCES}

1. Velmurugan, M., N. Chezhiyan and M. Jawaharlal. 2008. Influence of organic manures and inorganic fertilizers on cured rhizome yield and quality of turmeric (Curcuma longa L.) cv. BSR-2. Int. J. Agric. Sci., 4: 142-145.

2. Kumar, G. V. V., M. A. Aariffkhan and Hameedunisa Begum. 2000. Influence of mineral nutrient 
composition of turmeric rhizome on curcumin content of different cultivars. Int. J. Trop. Agric. 18: 265-269.

3. Hossain, M. A., Kenji Yamawaki, Hikaru Akamine and Yukio Ishimine. 2008. Weed infestation in turmeric in Okinawa, Japan. Weed Technol., 22:56-62.

4. Katan, J. 1981. Solar heating of soil for control of soilborne pests. Ann. Rev. Phytopathol., 19:311-336.

5. Panse, V. G. and P. V. Sukhatme. 1978. Statistical methods for Agricultural workers. Indian Council of Agricultural Research, New Delhi, p. 225.

6. Ahmed Almasoum, A. 1997. Plastic mulch colour effects on yield and quality of tomatoes. South Indian Hort., 46(1and2): 35-38.

7. Warade, A. D., V. S. Gonge, S. G. Bharad, P. G. Ingole and D. R. Nandre. 2008. Influence of integrated weed management on growth and yield of onion (Allium cepa L.). Plant Archives, 8: 325-328.

8. Aggarwal Sonia, B. N. Kalra and J. N. Raina.2003. Effect of mulches on soil hydrothermal regimes, weed incidence, yield and quality of ginger. J. Indian Soc. Soil Sci., 51:65-67.

9. Shaikh, A. A., S. G. Kumbhar and S. M. Jawale. 2005. Effect of production parameters on nutrient uptake in ginger. Int. J. Agric. Sci., 75: 216-217.

10. Manohar Rao, A., P. Venkataka Rao and Y. Narayana Reddy. 2004. Evaluation of turmeric cultivars for growth, yield and quality characters. J. Plantation Crops, 32: 20-25.

11. Jadhao, B. J., V. S. Gonge, D. M. Panchbai, Anjali Mohariya and I. R. Hussain. 2005. Performance of turmeric varieties (Curcuma longa L.) under varying levels of Zinc and Iron. Int. J. Agric. Sci., 1: 94-98.

12. Reddy, K. C. and K. M. Reddy. 2005. Differential levels of vermicompost and nitrogen on growth and yield in onion (Allium cepa L.)-radish (Raphanus sativus L.) cropping system. J. Res. ANGRAU, 33: 11-17.

13. Indiresh, K. M., B. C. Utaiah, P. H. Sridhara and B. K. Rao. 1990. Morphological, rhizome and yield characters of different turmeric varieties in coastal Karnataka. Mysore J. Agric. Sci., 24:484-490.

14. Cholke, S. M. 1993. Performance of turmeric (Curcuma longa L.) cultivars. M. Sc. (Ag.) Thesis submitted to University of Agricultural Sciences, Dharwad.

15. Rajpal Dalal, Vijaypal Singh and Anureet Kaur. 2006. Beneficial effects of mulching. Agrobios Newsletter, 5: 46-48.

16. Ratnambal, M. J. 1986. Evaluation of turmeric cultivars for quality. Plants and Human Nutrition, 36:243-252. 